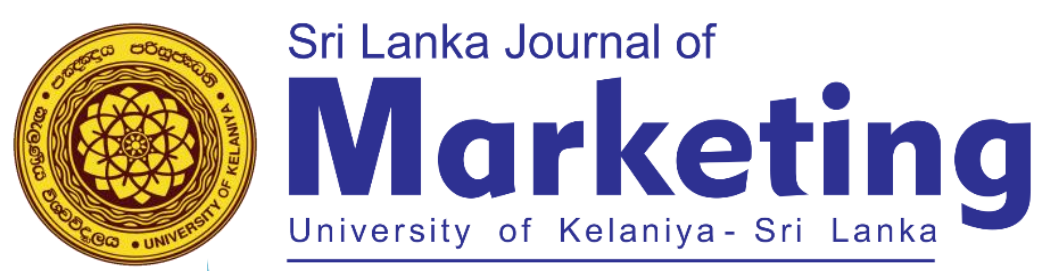

\title{
Avoidance of Eco-Tourism Labelled Hotels by the Domestic Tourists of Sri Lanka
}

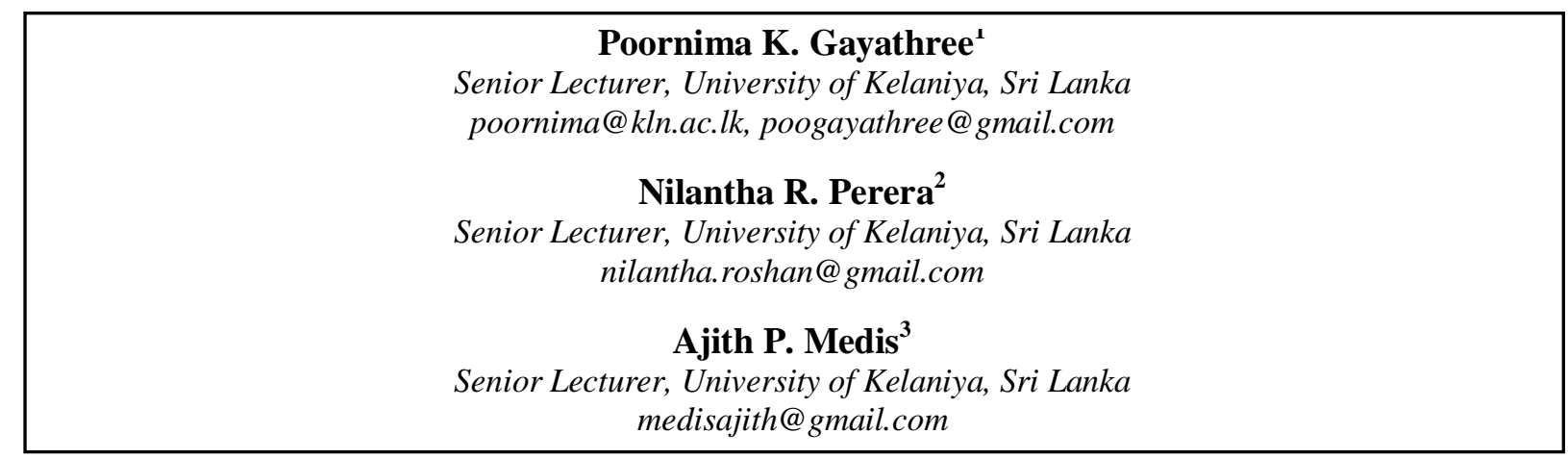

\section{ABSTRACT}

Modern consumers are living a consumerist lifestyle, which negatively impacts on the natural and the built environment. However, there is a trend towards environmental protection within society. It is clearly observed that green labels are everywhere and has become a marketing tool for companies, and this is common for tourist hotels as well. Ecotourism which is one form of ethical goods and services has been increasing worldwide. These tourists especially concern about natural and the built world. Therefore, they will neglect the products and services which harm the environment. Identifying that there is a gap in the literature about the consumer's avoidance of products and services which claims the "green", the study aims at, exploring the avoidance behavior of eco-labeled hotel brands by the ecotourists".

Keywords: Brand Avoidance, Eco-Tourism, Eco-Label Hotel Brands 


\section{INTRODUCTION}

Consumerism has become the main purpose of modern life of human. (Holt, 2005). Therefore, daily massive amounts of goods and services are produced resulting in exploiting the natural environment. This is clearly visible through the environmental pollution reported recently around the world. Therefore, protecting the environment has become a key objective of the modern era. Therefore, increasingly scholars are researching this topic. Bendell (1998) introduced two types of ethical consumerism patterns of consumers. They are, consumerist and citizen. Further, the author pointed out that, there can be positive \& negative ethical purchase behavior and consumer actions. Hence, when the consumers are buying goods and services either ethical products will be consumed willingly or will boycott or avoid unethical products and consumer actions etc. (As cited in Tallontire, Rentsendorj \& Blowfield, 2001). Boycotting products, opposing nuclear power, eco-travel and responsible tourism comes under ethical consumption patterns of the consumers (Witkowski \& Reddy, 2010). Out of the ethical goods and services mentioned, tourism is one of the fastest growing industries in the world and has a huge impact on the environment and society (EIT, n.d.). Therefore, increasingly attention was given about preserving the environment and the local community through the eco-tourism activities. According to the International Ecotourism Society (TIES), ecotourism was defined as, "responsible travel to natural areas that conserves the environment and improves the well-being of local people" (TIES, 1990). On the other hand, UNWTO defines sustainable tourism as, "tourism development with a balance between environmental, economic and socio-cultural aspects" (http://wwf.panda.org, n.d.). The difference between ecotourism and sustainable tourism comes from balancing the three circles of economics, environment and socio-cultural aspects but ecotourism discusses mainly conservation of the environment and transferring financial benefits to local people.

In the world context, the number of eco-tourists; those who involved in ecotourism, has been rising rapidly which gives an opportunity for eco-friendly accommodations (William, n.d.). The theoretical explanation of ecotourism shows three aspects such as environment, community, and education and highlights mainly less negative impact whilst connection with the green consumerism or whether the eco-tourist is a green consumer is questionable (Sharpley, 2006). When differentiating between Ecotourists, nature tourists, and sustainable tourists, in terms of concern on nature, learning and sustainability, eco-tourists score high for all three whilst other two groups score very less for two dimensions. That is, nature tourists score high on nature whilst sustainable tourist on sustainability (Mehmetoglu, 2010). This leads to the notion that the eco-tourists possess sustainable consumption patterns and can be considered possessing green consumption values. Green consumption also denotes that, green consumer willing to consume products and services which are less harmful and eco-tourists also willing to participate in the less harmful impact on the environment. Thus, with this clarification, it is argued that eco-tourists show environmentally friendly behavior. 
Anti-consumption has becoming a significant area of research recently among the consumer behavior researchers in the field of ethical consumption due to the rapidly increasing the number of ethical consumers (Rindell, Strandvik, \& Wilen, 2013; Chatzidakis \& Lee, 2012; Lee \& Ahn, 2016), which allows the identification of reasons against the consumption than the reasons for consumption (Chatzidakis \& Lee, 2012). The consumer's decision to purchase products will depend on the ethical practices of organizations and specifically, the CSR practices influence the purchasing intention. This means if the organization behaves unethically in terms of any type of business processes (labor practices, production practices, etc) the consumer will avoid purchasing its products or services (Papaoikonomou et al, 2011).

The anti-consumption related literature has given prominence to analyze the factors that result in consumers not involving in unethical consumption. However, less attention has been given on the psychological process and the personal characteristics of the ethical consumers in making consumption decisions which do not comply with the ethical attitudes. The traditional research on consumer behavior which focuses on the outward behaviors has not been able to fully discover the deeply rooted motivations for consumption. The study further specifies that anti consumption as an emerging area of study will uncover the reasons against consumption which has been failed to achieve through the traditional means of consumer behavior models (Chatzidakis et al, 2012; Lee et al, 2016). Rindell, et al (2013) specifies that ethical consumers avoid purchasing brands which do not match with the personal ethical considerations. Even though the green concept is well established in the developed nations, it is not now increasingly being inculcated into the Asian countries. In Sri Lanka "going green" is becoming popular (Samarasinghe, 2012).

It has been evident that the contribution of tourism to the Gross Domestic Product (GDP) increasingly becoming significant. According to the WTTC (2015) and (2016) report (Table 01), there has been a slight drawback in the direct and the total contribution of travel and tourism to the GDP.

Table 01: Contribution of Tourism to the GDP (Direct and Total)

\begin{tabular}{|l|l|l|l|}
\hline $\begin{array}{l}\text { \% direct contribution to } \\
\text { GDP }\end{array}$ & $\mathbf{2 0 1 4}$ & $\mathbf{2 0 1 5}$ & $\mathbf{2 0 1 6}$ \\
\hline $\begin{array}{l}\text { \% total contribution of } \\
\text { Travel \& Tourism to }\end{array}$ & $4.6 \%$ & $\begin{array}{l}\text { By }+3.6 \% \text { (Forecasted } \\
\text { increase in 2016) }\end{array}$ \\
GDP Source: World Travel and Tourism Council, 2015/2016 \\
\hline
\end{tabular}

Moreover, the contribution of tourism to GDP to Sri Lanka can be broadly divided into two areas based on the purpose of the visit; business and leisure. According to the statistics, $87 \%$ has been reported by 
the leisure and $13 \%$ by the business (WTTC, 2015) and in 2015 the value of the business has been increased up to $14 \%$ whilst leisure traveling decreased up to $86 \%$ (WTTC, 2016). Despite the fact that leisure traveling had a slight fall, leisure has been the most prominent reason for the tourists for traveling. Travelers seeking to visit within the island do not only limited to foreign travelers but also comprise of Sri Lankan travelers. WTTC (2016) reports that 35.1\% contribution to GDP out of travel and tourism comes from the expenditure of domestic compared to $64.9 \%$ of foreign expenditure in the year 2015. The report further specifies that domestic expenditure expected to grow by $7.2 \%$ in 2016 and thereafter increasing of 5.4\% per annum. The amount of domestic tourists has been growing rapidly in recent years and it is expected that it will be increased from 1 million tourists registered in the year 2012 to 2.5 million in the year 2016 (Lewes, 2013).

The five-year master plan of Sri Lanka Tourism Strategy specifies promoting domestic tourism as one of the main areas of concern. It further explains the increasing demand from domestic tourists with an increase of per capita income (Ministry of Economic Development, n.d.). Ecotourism is a vastly growing area within the world where a number of eco-tourist continue to grow annually. Despite the fact the Sri Lanka Eco Tourism Foundation established in 1998, the sector is still in the primitive stage in terms of the practices adopted which adversely effect on the behavioral intention of the eco-tourists (Arachchi, et al., 2015). According to a pilot study conducted by the researcher to get an idea about the perception of academics and managerial level employees in the industry regarding the "going green practices" of Sri Lankan companies, 7 out of 10 mentioned that "they are not happy about the green labeled company practices". Interestingly, in summarizing the reasons for the answer, respondents who were not happy specifically mentioned that cost minimization and profit motives are the main reason for labeling as "green" otherwise no any company do it with real purpose. Five respondents have mentioned that companies can do more for complying with green claims. All ten agreed that they are trying the level best to reduce the harm caused towards the environment. However, except three who mentioned that they are increasing the consumption of environmentally friendly goods and services another seven mentioned about recycling, disposing of garbage proper manner as the actions are taken so far to protect the environment. This further proves that academics and managerial level employees in Sri Lanka are aware of the environmental damage caused by consumption patterns and willing to contribute to protecting the environment. The study will be narrowed down to eco-tourism and will focus on "identifying the factors affecting the avoidance of eco-tourism labeled hotels and restaurants by the domestic tourists".

Rindell et al., (2013) argues that the ethical consumers might avoid brands due to the consistent negative evaluations of a company over time and due to the mismatch between personal values and the company values. This poses a question "does the ethical consumers reject brands which claims to be green". Chatzidakis et al., (2012) specifies that studying the negative side of the consumption equation will 
reveal more about consumer behavior. Most importantly the research study specifies three areas of interest to the future research studies; reasons against unethical companies which acts as reasons for ethical companies, reasons preventing boycotting of unethical companies and reasons against boycotting of ethical companies. However, very less attempt has been given to study the factors which prevent consumers from using ethical products and services. This further proves that the identifying reasons "why ethical consumers avoid purchasing green brands and continue the consumption of nongreen brands (unethical brands)" is paramount important. It has been observed that there is very less number of studies which has studied the "green consumers brand avoidance". Majority of the studies which has focused on barriers to ethical consumption were the qualitative studies focusing on the general ethical consumption behavior. Brand avoidance literature has not given attention to study brand avoidance in terms of price value perceptions and personal value considerations in making the ethical consumption decisions, especially in the context of eco-tourism. This proves that there is a wide literature gap that will be filled through the study. According to the above explanation the research problem that the study intends to address would be, "what leads to the avoidance of eco-label hotel brands by the eco-tourists within Sri Lanka".

\section{BACKGROUND THEORY AND CONCEPTS}

According to Chatzidakis et al. (2012) the phenomena of the attitude-behavior gap, which has been highlighted by many scholars who have been studying the ethical consumption behavior, is challenged through the new perspective of looking at the actual behavioral avoidance for the green products. Thus, the broad area which is under concern for the research is anti-consumption. Editorial (2009) specifies that anti-consumption is a broader phenomenon than ethical consumption, sustainability or green consumption. There are four main sub-areas that can be studied from the reasons theory perspective; ethical concerns, environmental concerns, consumer resistance, and symbolic concerns. The author specifies that studying reasons against is equally important as studying reasons for which has been derived from the reasons theory (Chatzidakis et al., 2012). Accordingly, the research would focus on reasons against green consumption by the Sri Lankans. It will be studied the phenomena which are emerging within the area of anti-consumption which is called as "brand avoidance".

\subsection{Anti-Consumption}

Anti-consumption related literature has been increasing ever since the first symposium by the International Center for Anti-consumption research (ICAR) in 2006. (Lee, et al., 2013). Anticonsumption related literature will add more value to the consumer behavior literature by going beyond the motivations of conventional variables such as values, norms and behaviors (Lee et al, 2013; Chatzidakis et al, 2012). Motivations for anti-Consumption falls under two main facets; collective anticonsumption and personal. That means specifically targeting multinational firms or activities by 
companies or involving green consumption and avoiding a highly consumerist lifestyle. Accordingly, there are four types of anti-consumption which are as mentioned in figure 01 below (Kozinets, et al., 2010).

Figure 01: Types of Anti-Consumption

\begin{tabular}{|c|c|c|c|}
\hline \multirow{4}{*}{ 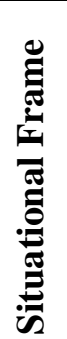 } & $\begin{array}{l}\text { Specific } \\
\text { (Brand, Nation) }\end{array}$ & Activist & Expressive \\
\hline & \multirow{2}{*}{$\begin{array}{l}\text { General } \\
\text { (eg: Green) }\end{array}$} & Utopian & Transformative \\
\hline & & Moral/Collective & Personal \\
\hline & \multicolumn{3}{|c|}{ Motivational Frame } \\
\hline
\end{tabular}

Source: Kozinets, Handelman, \& Lee (2010)

In contemporary society, there are consumers who do not participate in anti-consumption. Yuksel (2013) pointed out that part of the consumers is not participating in anti-consumption due to "out of sight, out of mind, urge for freedom and self-defense and counterarguments-skepticism or accounts". The study specifically focuses on consumer boycotts against the unethical business practices of cooperates. In contrast it has been identified that the carrotmob (derives by combining carrot and stick adage and flash mob) is an effective technique that assists the consumer to show the concern over environment and the consumers who seriously concern on the environmental protection willing to participate in carrotmob given the fact that organizations involved in pro-environmental activities (Hutter \& Hoffmann, 2013). It has been further argued that consumers with strong ethical concerns reject brands due to three reasons; overall evaluation of the companies which form a positive or negative attitude towards the brand, companies communication of activities which result in acceptance or rejection of a brand and the tradeoff between the ethical consumption and brands (Rindell et al, 2013). Anti-consumption related literature has given less prominence to analyze the deep routed motivations against non-participation of anti-consumption activities, than outward factors (Chatzidakis et al, 2012; Lee et al, 2016). Chatzidakis et al. (2012) further specify that green consumption, ethical concerns, and environmental concerns also come under the purview of anti-consumption. Whereas anti-consumption includes other areas such as consumer resistance, anti-branding, anti-globalization, culture jamming, and voluntary book clubs, etc. (Kozinets et al., 2010). The research will look anti-consumption by combining the perspectives of green consumption and brand avoidance. The two areas will be discussed in the following sub topics.

\subsection{Green Marketing/Green Consumerism/Ethical Consumerism}

Ethical consumption related research work started back in the 1970s where the researches started studying about the socially conscious consumption patterns. The academic work published thereafter 
contained the studies which are specifically focused towards the environmental concern (Cooper-Martin \& Holbrook, 1993).

Polonsky (1994) defined green marketing as "green or environmental marketing consists of all activities designed to generate and facilitate any exchanges intended to satisfy human needs or wants, such that the satisfaction of these needs and wants occurs, with minimal detrimental impact on the natural environment" (Polonsky, 1994, p 2). According to the definition of green marketing has been defined from the marketer's point of (or an organizational point of view) which elaborates the requirement to satisfy human requirements with minimal impact on the environment.

In buyers, perspective ethical consumerism can be defined as, "the practice of purchasing goods and services which has been manufactured in a way with less impact on the society and/or the environment and rejecting the goods and services which will have a harmful impact on the society or the environment. Ethical goods include ethical goods and services, eco-travel and transport, green home, ethical personal products and ethical finance (The Institute of Grocery Distribution, n.d.).

\subsection{Brand}

According to American Marketing Association (AMA) glossary a brand has been defined as a "Name, term, design, symbol, or any other feature that identifies one seller's good or service as distinct from those of other sellers" (American Marketing Association, n.d.). After reviewing many definitions for the brand which had pros and cons Wood (2000) defines a brand as "a mechanism for achieving competitive advantage for firms, through differentiation (purpose). The attributes that differentiate a brand provide the customer with satisfaction and benefits for which they are willing to pay (a mechanism)" (Wood, 2000, p 666). Wood (2000) definition will be adopted for the describing a brand since it gives a comprehensive view of the brand than just merely referring as a name, term, design, symbol or other features as highlighted by the AMA definition. Highlighting feature of the definition suggested by Wood (2000) is the customers are willing to pay for a brand because of the attributes that the brand provides. Thus, the study will consider a green brand as a one which communicates or claims to have green attributes and produced with less harm to the society and the environment, because of which the green consumers are attracted to purchase such green brand.

\subsection{Brand Loyalty}

Brand loyalty can be explained as people repeatedly buy a product or a brand rejecting other brands (lexicon.ft.com, n.d.). Similarly, AMA defines the term brand loyalty as ".The situation in which a consumer generally buys the same manufacturer-originated product or service repeatedly over time rather than buying from multiple suppliers within the category" or "the degree to which a consumer consistently purchases the same brand within a product class" (American Marketing Association, n.d.). 
Oliver (1999) defines the brand loyalty as, "a deeply held commitment to rebuy or repatronize a preferred product/service consistently in the future, thereby causing repetitive same-brand or same brand-set purchasing, despite situational influences and marketing efforts having the potential to cause switching behavior" Oliver, 1999, p. 34). The definition which will be followed for the study is Oliver (1999) definition which will highlight the consumers' loyalty towards non-green brands.

The factors that significantly impact on the brand loyalty includes, Brand Trust, Brand Benefits, Price Consciousness (Kumar \& Advani, 2005) and the brand trust is affected by brand predictability, brand liking, brand competence, brand reputation, trust in the company (Lau \& Lee, 1999). In addition to these factors, Yoo \& Park (2016) has identified that the hedonic, utilitarian, creative achievement and social value directly impact on the satisfaction of consumers which in return effect on the brand loyalty. The researchers have attempted to study the opposite of brand loyalty which is referred to as the antibrand loyalty. Oliva (1992) has specified that anti-brand loyalty as synonymous to brand avoidance (As cited in Lee, 2008). However, brand avoidance and brand switching are not the same. Brand avoidance is a continuance disliking for a brand whilst brand switching is a onetime response towards a negative experience (Lee, 2008).

\subsection{Brand Trust}

The brand trust has been defined "as the willingness of the average consumer to rely on the ability of the brand to perform its stated function" (Chaudhuri \& Holbrook, 2001, p 82). Brand trust strongly impacts on the brand loyalty (Ribbink, et al., 2004) whilst brand trust impact on the purchased loyalty (described as the customer's willingness to purchase a brand again) and the attitudinal loyalty (level of commitment of the average customer towards a brand (Chaudhuri \& Holbrook, 2001). Opposite of the term trust is distrust. According to the Oxford Dictionary definition, distrust is "the feeling that someone or something cannot be relied upon". Lewicki, Mcallister, \& Bies (1998) defines distrust as the right opposite of trust. According to a study conducted regarding the defensive consumer revealed that consumer creates a negative idea or distrust regarding the overall advertising in response to a deceptive advertisement which in turn will effect on the firm which sells the products (Darke \& Ritchie, 2007). According to the description of approach/avoidance motivation, when the consumers require attaining a goal due to positive aspects but at the same time wants to avoid it because of some negative aspects, consumers will get stressed. Specially the avoidance dimension will lead to negative emotions. According to that explanation, it is reasonable to argue that reasons for avoiding the green brand will create negative trust towards the green brand and the negative trust for the green brand will lead to green brand avoidance. Thus, the study will focus on determining the impact of factors of avoidance on the green brand trust and which will in return impact on the green brand avoidance. 


\subsection{Brand Avoidance}

Lee (2008) was the first ever researcher who has defined the meaning of brand avoidance after taking the meaning of avoidance from psychology. According to him, brand avoidance can be defined as the behaviors and attitudes consumers have regarding a brand, as motivated by the negative meanings/consequences associated with the brand (Lee, 2008, p 6). Lee (2008) further explains that non-choice is different from anti-choice where anti-choice means the products are within the consideration set of the consumers and non-choice refers to the products or services are not within the range of consumers consideration set. For the purpose of continuing with the research as highlighted by Lee (2008), anti-choice will be considered as the considered phenomena which lead to avoidance of brands.

There are three types of brand avoidance; experiential, identity and moral brand avoidance (Lee, et al., 2009) and deficit value avoidance and advertising avoidance (Knittel, et al., 2016). Brand avoidance as an area of research is crucial but has given less attention by the researchers (Knittel, et al., 2016).

\subsection{Eco-Tourism}

There are two terms that should be differentiated before moving onwards with the research; Eco-tourism and sustainable tourism. According to the International Ecotourism Society (TIES), ecotourism was defined as, "responsible travel to natural areas that conserves the environment and improves the wellbeing of local people" (TIES, 1990). Web page of TIES explains the principles of ecotourism which includes, minimizing the impact, aware about the environment and culture and build respect, giving positive experience to both the visitors and host, giving the financial benefits for conservation and local people, empowerment of local people, being sensitive to host countries political, environmental, and social climates. Broadening the concept of ecotourism further, TIES (2015) definition has now introduced as, "responsible travel to natural areas that conserves the environment, sustains the wellbeing of the local people, and involves interpretation and education" (TIES, 2015). Thereby updates have been introduced to the principles of ecotourism, giving guidelines for those who adopt ecotourism activities. There are other terms that go hand in hand with the ecotourism, which are called as nature tourism and sustainable tourism which also explains some routes to sustainability concept. UNWTO defines sustainable tourism as, "tourism development with a balance between environmental, economic and socio-cultural aspects" (Anon., n.d.). The difference between ecotourism and sustainable tourism comes from balancing the three circles of economics, environment and socio-cultural aspects but ecotourism discusses mainly conservation of the environment and transferring financial benefits to local people.

In the world context, the number of eco tourists; those who involved in ecotourism, has been rising rapidly which gives an opportunity for eco-friendly accommodations (William, n.d.). The theoretical 
explanation of ecotourism shows three aspects such as environment, communit, and education and highlights mainly less negative impact whilst connection with the green consumerism or whether the eco-tourist is a green consumer is questionable (Sharpley, 2006). When differentiating between Ecotourists, nature tourists, and sustainable tourists, in terms of concern on nature, learning and sustainability, eco-tourists score high for all three whilst other two groups score very less for two dimensions. That is, nature tourists score high on nature whilst sustainable tourist on sustainability (Mehmetoglu, 2010). This leads to the notion that the eco-tourists possess sustainable consumption patterns and can be considered possessing green consumption values. Green consumption also denotes that, green consumer willing to consume products and services which are less harmful andeco-tourists also willing to participate in the less harmful impact on the environment. Thus, with these clarifications, it is argued that eco-tourists show environmentally friendly behavior.

\subsection{Approach/Avoidance Motivation}

Theory of approach/avoidance explains that the stress arises in the consumer's mind when he/she observes a positive and a negative aspect in the same situation (Shiffman, et al., 2015). This applies to green brand purchasing when the consumer has a list of positive attitudes towards consuming green products since it has less harm towards the environment. At the same time, there are factors that will lead to avoid the purchasing green products due to economic rationalizations, institutional dependency, development realism (Eckhardt et al., 2010), situational context and actual behavioral control (Carrington, et al., 2010).

\section{CONCEPTUAL FRAMEWORK AND OPERATIONALIZATION}

The purpose of the research is to identify whether the green brand avoidance indicates the lack of brand trust associated due to experience, identity, moral, deficit value, and advertising avoidance. The first part of the section will focus on defining the predictor variables and the second literature will be brought to build the relationships. Finally, operationalization of variables will be presented.

\subsection{Hypothesis Development}

\subsubsection{Perceived Quality and Brand Avoidance}

Perceived quality has been defined as the opinion of consumer that the brand's/product's ability to fulfill the expectations (Businessdictionary.com, n.d.). Tsiotsou (2006) defines the term perceived quality as, "the consumer's judgment about a product's overall excellence or superiority" (Tsiotsou, 2006, p 210). The scholars have concluded that there is a significant influence of perceived quality on the purchasing intention (Choi \& Kim, 2013; Ariffin, Yusof, Putit, \& Shah, 2016). Perceived quality has been identified both as an antecedent and a mediator for the purchasing intention (Tsiotsou, 2006). According to the TPB model, consumer attitude has a strong influence on purchasing intention. Attitude can be explained 
as, an overall evaluation regarding a particular object (Shiffman et al., 2015). When the consumer has a particular evaluation regarding the quality of the organization in terms of its environmental concerns it will certainly lead decision making. According to Howard and Sheth model of consumer behavior, one of the outcomes of the consumer complex buying decision making is the brand choice. In addition to that, purchase, intention, attitude, and attention is available. Rindell et al., (2013) specifies that consumer evaluation of company activities over time leads to the decision of brand avoidance when the perception of consumers towards the company is negative.

The concept of perceived quality has always been studied in relation to the intention and the behavior or with the perceived value (Tsiotsou, 2006; Weisstein, Asgari, \& Siew, 2014). However, the study will focus on brand avoidance as the behavioral outcome of the perceived quality which has not been studied so far. However, the literature argues that the opposite aspect of the consumption equation will be important as the positive aspect which will reveal the behavior of consumption patterns of the modern consumer (Rindell et al., 2013; Chatzidakis et al., 2012).

Thereby the following hypothesis has been drawn based on the argument built above.

H 1: Perceived quality strongly impacts on the Eco labeled hotel brand avoidance

\subsubsection{Self-Identity and the Brand Avoidance}

Self-identity has been defined as the unique characteristic of an individual that certainly make him or her different and standalone from others (Merriam Webster, n.d.). According to the identity theory perspective impact of social to the self and impact of self to the social are different methods along which the identity theory has been developed. Out of these, the second method discusses the internal processes of human beings (Stryker \& Burke, 2000). Identity theory based on the self-perspective has been studied in the context of ethical consumption patterns (Khare, 2015; Whitmarsh \& O'Neill, 2010). Moreover, many studies have attempted to study the impact of self-identity on behavior and behavioral intention (Whitmarsh et al., 2010). Green self-identity has a significant influence on environmental friendly buying behavior (Khare, 2015; Whitmarsh et al., 2010). Lee (2008) describes that the individuals are living the life to match with the self-identities. Brands, on the other hand, deliver a set of values and meanings. If the consumers receive negative information regarding the brands through the advertising, branding packaging or word of mouth, such brands will be rejected by the consumers. Accordingly, there are three sub-themes that have been developed under identity avoidance; negative reference group, inauthenticity, and DE individuation. This describes that the consumers will reject brands in order to get away from a negative reference group when the brand loses its authenticity due to not symbolizing the desired brand values when the consumption of a brand leads to losing the self-identity (Lee, 2008). The green brands also make a certain bundle of promises and values to the customers. The literature highlights that green consumers possess certain specific values that drive them in consuming green products. Unlike the past studies which have focused on identifying the impact of self-identity on the 
environmentally friendly buying behavior, this study argues that consumers who prefer purchasing products which are environmentally friendly will reject brands if the desired values are not delivered. This argument is supported by the study conducted by Rindell et al., (2013) which specify that the ethical consumers will reject brands based on the evaluation of company activities over time if the expectations are not met. Therefore the researcher defines self-identity as, "unmet promises by the brand will cause in rejecting the brand since the brand values and consumer self-identities do not match". Thereby the following hypothesis can be derived.

\section{H 2: Self-Identity is strongly impacted by the Eco labeled hotel brand avoidance}

\subsubsection{Moral Obligations and Brand Avoidance}

Moral obligations can be defined as, responsibility considerations that are aroused out of the difference between, what is right and what is wrong (Thefreedictionary.com, n.d.). According to the Hunt-Vitell's theory of ethics, when an individual is facing an ethical related problem, the consumer will see a possible set of alternatives. Based on the perceived set of alternatives there will be two types of evaluations as, deontological and teleological. Deontological evaluation is based on the inherent norms, personal values and the rules of behavior. This does not focus on the consequences of the behavior. On the other hand, teleological evaluations are on the stance that, the consumer will evaluate the probability of occurrence and the consequences on stakeholders. Accordingly, the researchers in the field of consumer ethics have researched about the ethical judgments by the consumers for ethical problems that are encountered (Hunt \& Vitell, 2006). Moral obligations have been added as an additional dimension in order to test the TPB by researchers in addition to the self-identity (Chatzidakis, et al., 2004). In contrast to measuring the behavioral intention and the behavior consumption of ethical products based on moral obligations, Rindell et al., (2013) argue that if ethical consumers face a tradeoff between the personal ethical considerations and the company activities it will lead to avoiding the brands. This dimension has been first introduced under the brand avoidance literature by, Lee (2008) which describes the concept moral avoidance as, the consumer rejecting a brand because of its being unethical and harmful to the entire world. Accordingly, there are two main themes called, country of origin and anti-hegemony. Consumer rejects brands produced by certain countries because of its negative effect on the world which is the description that comes under the country of origin. Antihegemony means dominant brands and corporates which can create harm to the world through, negatively impact on human life and environment by adopting unethical practices (Lee, 2008).

Green brands and claims of green brands which specifies that the production process, employment, and the entire business processes are done through ethical means but if actually, the brands do not involve in ethical terms will disappoint the green customers. Thus it will create distrust with the brand which will result in avoiding the brand. The study argues that, if personal moral obligations do not comply with the company activities, the consumers will avoid such brands. This complies with the arguments 
put forward by Rindell et al., (2013) which explains the moral obligations and the company activities trade-off. Thus moral obligations for the purpose of the study will be defined for as, "consumers with ethical consumption will avoiding the green brands due to its business practices which are in contradictory with the personal moral obligations".

Thereby the following hypothesis can be derived to depict the relationship between the moral obligation and brand avoidance.

H 3: Moral obligation is strongly impacted by the Eco labeled hotel brand avoidance

\subsubsection{Perceived Quality and Perceived Value}

Investopedia.com defines perceived value as the relative worth of the product that the consumer possesses in the mind regarding the product or the service. It is quite important recognizing that there is an ample amount of research that has been conducted with the relationship between quality and value. However, the concept of customer value still has avenues for the research since still there is no agreedupon common meaning attached to this term (Gallarza, Gil-Saura, \& Holbrook, 2011). According to the literature perceived value has two perspectives namely; economic and psychological dimensions. Economical dimension discusses the perceived price which discusses the transaction value. On the other hand psychological dimension discuss the cognitive and the affective elements which are influencing on the product choice and the brand choice (Gallarza et al., 2011; Medeiros, Ribeiro, \& Cortimiglia, 2015). Gallarza et al., (2011) strongly argue that the relationship between the value and loyalty is yet to be explored by the academics.

According to the literature quality strongly influence the perceived value (Gallarza et al., 2011; Medeiros, Ribeiro, \& Cortimiglia, 2015; Cheung, Lam, \& Lau, 2015). Even though the scholars have attempted in studying the relationship between perceived quality and the perceived value, within the context of eco-labeled hotel brands the literature is very less observed.

Based on the argument built above the following hypothesis has been built H 4: Perceived quality strongly influence on the perceived value

\subsubsection{Self-Identity and the Brand Trust}

The brand trust has been defined "as the willingness of the average consumer to rely on the ability of the brand to perform its stated function" (Chaudhuri et al., 2001, p 82). On the other hand, Self-identity has been defined as the unique characteristic of an individual that certainly make him or her different and standalone from others (Merriam Webster, n.d.). Based on the self-identity theory, when the consumers perceive a certain product do not match with the self-identity, it will lead to creating a lower trust towards the brand (He, et al., 2012). The study of He et al. takes the stance from the social identity perspective. However, the researcher argues that when the consumer is identifying him or herself with 
the brand the trust towards the brand is increasing. The author further mentions that it is vital for studying consumer resistance towards negative information. According to Lee (2008) when the consumer perceives that, his or her identity does not match with the claims of the organization, the consumer will avoid purchasing such brands. There has not been any study which has tested the mismatch of organizational claims and the identity of consumers towards the brand trust; especially with considering the context of eco-labeled products.

Accordingly, the following hypothesis has been derived based on the above argument.

H 5: Self-Identity strongly influence on the brand trust

\subsubsection{Moral Obligation and the Brand Trust}

Thefreedictionary.com defines Moral obligations as, responsibility considerations that are aroused out of the difference between, what is right and what is wrong. On the other hand, the brand trust has been defined "as the willingness of the average consumer to rely on the ability of the brand to perform its stated function" (Chaudhuri et al., 2001, p 82). Gustafsson (2005) specifies that ethical considerations will effect on the trust created for the brands. The consumers who perceive that the organizational activities are unethical will identify that it is not matching with the personal ethical considerations. Thus, this will lead to creating less trust in the brand. Accordingly, the following hypothesis is developed based on the argument built above.

Hypothesis 6: Moral Obligation significantly influence the Brand Trust

\subsubsection{Perceived Value and the Eco Labeled Hotel Brand Avoidance}

Investopedia.com defines perceived value as the relative worth of the product that the consumer possesses in the mind regarding the product or the service. On the other hand, brand avoidance can be defined as the behaviors and attitudes consumers have regarding a brand, as motivated by the negative meanings/consequences associated with the brand (Lee, 2008, p 6). If the relative worth of the product is high from the consumer's perspective, eco-labeled hotel brand avoidance will be lower. Rindell et al., (2013) suggest that studying the impact of trade-off strategies; consumer select the brands which least harmful and value-oriented factors on brand avoidance as possible areas of study. Accordingly, the following hypothesis is developed based on the argument built above.

H 7: Perceived Value significantly influence on the Eco Labeled Hotel Brand Avoidance

\subsubsection{Brand Trust and the Eco Labeled Hotel Brand Avoidance}

Brand avoidance can be defined as the behaviors and attitudes consumers have regarding a brand, as motivated by the negative meanings/consequences associated with the brand (Lee, 2008, p 6). On the other hand, brand trust has been defined "as the willingness of the average consumer to rely on the ability of the brand to perform its stated function" (Chaudhuri et al., 2001, p 82). The researcher argues 
that brand trust and brand avoidance are negatively correlated. When the customer has a low trust towards the brand, he or she will avoid purchasing the brand.

Accordingly, the following hypothesis is developed based on the argument built above.

H 8: Perceived Value significantly influence on the Eco Labeled Hotel Brand Avoidance

\subsubsection{Willingness to Pay on the Eco Labeled Hotel Brand Avoidance}

Yanga, Solgaarda \& Haider (2015) specifies that there are three types of consumers as, price sensitive, value-seeking and green consumers. Green consumers also come under different levels such as, purely green driven and those who care for the environment but reflects less in the behavior. The study specifies that according to Ginsberg and Bloom (2004), there are three main types of green consumers, high green (green back green, true blue-green), medium green (spouts) and low green (grousers and basic browns) (As cited in Weisstein et al., 2014). Weisstein et al., (2014) argue that different levels of green consumers will perceive price promotions of the organizations differently which will in turn effect on the purchasing intention. This reflects that the green consumers purchasing behavior are significantly influenced by the willingness to pay which is primarily based on the level of greenness. The study does assume that the sample extract includes consumers who possess high income and the ability to pay. Thus, would control the particular variable and its influence on the Eco labeled hotel brand avoidance. H 9: Willingness to Pay significantly influence on the Eco Labeled Hotel Brand Avoidance

Figure 02: Proposed Conceptual Framework

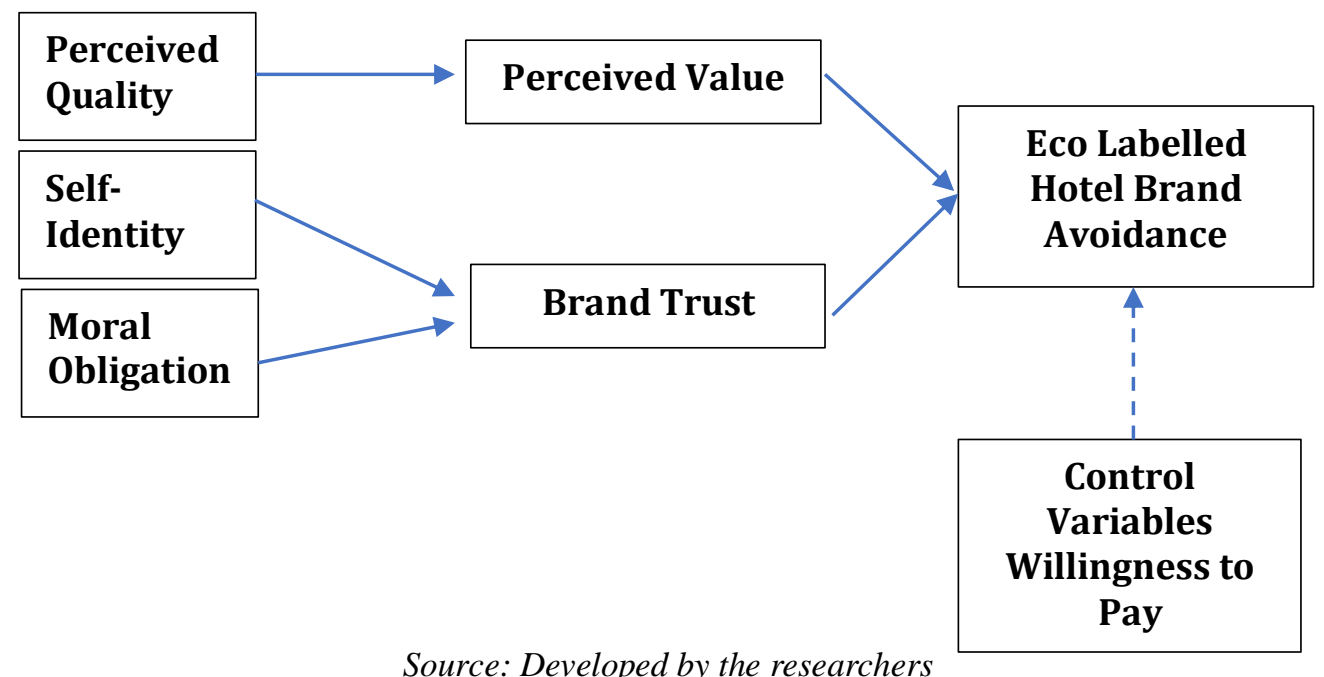




\section{MATERIALS AND METHODS}

The paper has reviewed literature from the research articles indexed in Science Direct, JSTOR, Emerald Insight, Google scholar and open source data bases. This paper is a concept paper which was used, "systematically review approach" and the unit of analysis is "a journal".

\section{FINDINGS AND CONCLUSIONS}

Today concerns on protecting the environment have been rising rapidly than any era in the past. Out of the ethical goods, eco-tourism considered as one of the most important areas. Whether it is locals or foreign, tourists are playing a critical role in a developing country's economy. Out of these tourists, eco-tourist will add significant value to the country, because of the concern given towards protecting the natural and built environment. Hence the eco-tourists will neglect the products and services, especially the places which provides accommodation which has false claims regarding protecting the environment. There is a huge trend that, the hotels, restaurants to claim that protection of the environment via saving resources as key. There are fewer studies conducted regarding the avoidance of eco-labeled hotel brands by tourists in the literature. Identifying that there is a gap in the literature about the consumers' avoidance of products and services which claims the "green", the study aims at, exploring the avoidance behavior of eco-labeled hotel brands by the eco-tourists".

\section{REFERENCES}

[1] American Marketing Association, n.d. https://www.ama.org/resources, Available at: https://www.ama.org/resources/Pages/Dictionary.aspx?dLetter=B

[2] Anon.,http://wwf.panda.org., Available at: http://wwf.panda.org/what we do/how we work/our global goals/oceans/solutions/reducing tourism_impact/difference between ecotourism sustainable tourism.cfm

[3] Arachchi, R. S., Yajid, M. S. \& Khatibi, A., 2015. Eco-Tourism Practices in Sri Lankan Eco Resorts: An Analysis of Satisfaction and Behavioral Intention of Eco-Tourists. International Journal of Business and Social Science, 6(10), pp. 211-226.

[4] Ariffin, S., Yusof, J. M., Putit, L. \& Shah, M. I. A., 2016. Factors Influencing Perceived Quality and Repurchase Intention Towards Green Products. Procedia Economics and Finance, Volume 37 , p. $391-396$.

[5] Businessdictionary.com, http://www.businessdictionary.com/definition/perceivedquality.html. [Online], Available at: http://www.businessdictionary.com/definition/perceivedquality.html

[6] Carrington, M., Neville, B. \& Whitwell, G., 2010. Why Ethical Consumers Don't Walk Their Talk: Towards a Framework for Understanding the Gap Between the Ethical Purchase 
Intentions and Actual Buying Behaviour of Ethically Minded Consumers. Journal of Business Ethics, Volume 97, p. 139-158.

[7] Chatzidakis, A., Hibbert, S., Mittusis, D. \& Smith, A., 2004. Virtue in Consumption? Journal of Marketing Management, Volume 5-6, pp. 526-543.

[8] Chatzidakis, A. \& Lee, M., 2012. Anti-Consumption as the Study of Reasons against. Journal of Macromarketing, pp. 1-14.

[9] Chaudhuri, A. \& Holbrook, M. B., 2001. The Chain of Effects from Brand Trust and Brand Affect to Brand Performance: The Role of Brand Loyalty. Journal of Marketing, Volume 65, p. 81-93.

[10] Cheung, R., Lam, A. Y. \& Lau, M. M., 2015. Drivers of green product adoption: the role of green perceived value, green trust and perceived quality. Journal of Global Scholars of Marketing Science: Bridging Asia and the World, 25(3), pp. 232-245.

[11] Choi, E. J. \& Kim, S., 2013. The Study of the Impact of Perceived Quality and Value of Social Enterprises on Customer Satisfaction and Re-Purchase Intention. International Journal of Smart Home, pp. 239-252.

[12] Cooper-Martin, E. \& Holbrook, M. B., 1993. Ethical Consumption Experiences and Ethical Space. NA - Advances in Consumer Research Volume, Volume 20, pp. 113-118.

[13] Darke, P. R. \& Ritchie, R. J., 2007. The Defensive Consumer: Advertising Deception, Defensive Processing, and Distrust. Journal of Marketing Research, Volume XLIV, p. 114127.

[14] Eckhardt, G. M., Belk, R. \& Devinney, T. M., 2010. Why don't consumers consume ethically? Journal of Consumer Behaviour, Volume 9, p. 426-436.

[15] Editorial, 2009. Anti-consumption: An overview and research agenda. Journal of Business Research, Volume 62, pp. 145-147.

[16] EIT, n.d. http://www.climate-kic.org/case-studies/defining-carbon-footprints-of-tourismpackages/. [Online], Available at: http://www.climate-kic.org/case-studies/defining-carbonfootprints-of-tourism-packages/

[17] Gallarza, M. G., Gil-Saura I. \& Holbrook, M. B., 2011. The value of value: Further excursions on the meaning and role of customer value. Journal of Consumer Behaviour, Volume 10, p. $179-191$.

[18] Ginsberg, J. M. \& Bloom, P. N., 2004. Choosing the Right Green-Marketing Strategy. MIT Sloan Magazine Review. 
[19] Gustafsson, C., 2005. Trust as an instance of asymmetrical reciprocity: an ethics perspective on corporate brand management. Business Ethics: A European Review, Volume 14, p. 142 150 .

[20] He, H., Li, Y. \& Harris, L., 2012. Social identity perspective on brand loyalty. Journal of Business Research, Volume 65, p. 648-657.

[21] Holt, D. B., 2005. An Interview with Juliet Schor. Journal of Consumer Culture, 5(1), p. 5-21.

[22] Hunt, S. D. \& Vitell, S. J., 2006. The General Theory of Marketing Ethics: A Revision and Three Questions. Journal of Macromarketing, Volume 26, pp. 143-153.

[23] Hutter, K. \& Hoffmann, S., 2013. Carrotmob and Anti-consumption: Same Motives but Different Willingness to Make Sacrifices?. Journal of Macromarketing, 33(3), pp. 217-231.

[24] Khare, A., 2015. Influence of green self-identity, past environmental behaviour and income on Indian consumers' environmentally friendly behaviour. Journal of Global Marketing Science, 25(4), pp. 379-395.

[25] Knittel, Z., Beurer, K. \& Berndt, A., 2016. Brand avoidance among generation Y consumers. Qualitative Market Research: An International Journal, 19(1).

[26] Kozinets, R., Handelman, J. \& Lee, M., 2010. Don't read this; or, who cares what the hell anti-consumption is, anyways?. Consumption Markets \& Culture, 13(3), pp. 225-233.

[27] Kumar, S. \& Advani, J., 2005. Factors Affecting Brand Loyalty: A study in an emerging market on fast moving consumer goods. Journal of Customer Behaviour, Volume 4, pp. 251-275.

[28] Lau, G. \& Lee, S., 1999. Consumers' Trust in a Brand and the Link to Brand Loyalty. Journal of Market - Focused Management, pp. 341-370.

[29] Lee, M., 2008. Brands We Love to Hate: An Exploration of Brand Avoidance, s.l.: The University of Auckland.

[30] Lee, M. \& Ahn, C., 2016. Anti-Consumption, Materialism, and Consumer Well-Being. The Journal of Consumer Affairs, 50(1), p. 18-47.

[31] Lee, M., Cherrier, H. \& Belk, R., 2013. Journal of Macromarketing Special Issue: AntiConsumption Research and Society. Journal of Macromarketing, 33(3), pp. 187-189.

[32] Lee, M., Motion, J. \& Conroy, D., 2009. Anti-consumption and brand avoidance. Journal of Business Research, p. 169-180.

[33] Lewes, D. E., 2013. https://srilankawonderofasia.wordpress.com/tag/sri-lankan-tourism/. [Online], Available at: https://srilankawonderofasia.wordpress.com/tag/sri-lankan-tourism/ 
[34] Lewicki , R. J., Mcallister, D. J. \& Bies, R. J., 1998. Trust and Distrust: New Relashioships and Realities. Academy of Management Review, 23(3), pp. 438-458.

[35] Medeiros, J. F., Ribeiro, J. L. D. \& Cortimiglia, M. N., 2015. Influence of Perceived Value on Purchasing Decisions of Green Products in Brazil. Journal of Cleaner Production.

[36] Mehmetoglu, M., 2010. Accurately Identifying and Comparing Sustainable Tourists, NatureBased Tourists, and Ecotourists on the Basis of Their Environmental Concerns. International Journal of Hospitality \& Tourism Administration, 11(2), pp. 171-199.

[37] Merriam Webster, h.d. http://www.merriamwebster.com/dictionary/self\%E2\%80\%93identity. [Online], Available at: http://www.merriamwebster.com/dictionary/self\%E2\%80\%93identity

[38] Ministry of Economic Development, n.d. Tourism Development Strategy 2011-2016, s.l:: Ministry of Economic Development.

[39] Oliver, R. L., 1999. Whence Consumer Loyalty? Journal of Marketing, Volume 63, pp. 33-44.

[40] Papaoikonomou, E. \& Ryan, G., 2011. Towards a Holistic Approach of the Attitude Behaviour Gap in Ethical Consumer Behaviours: Empirical Evidence from Spain. International Advances in Economic Research, 17(1), pp. 77-88.

[41] Polonsky, M. J., 1994. An Introduction To Green Marketing. Electronic Green Journal.

[42] Ribbink, D., Riel, A. C. v., Liljander, V. \& Streukens, S., 2004. Comfort your online customer: quality, trust and loyalty on the internet. Managing Service Quality, 14(6), pp. 446 - 456.

[43] Rindell, A., Strandvik, T. \& Wilen, K., 2013. Ethical consumers' brand avoidance. Journal of Product \& Brand Management, 22(7), pp. 484 - 490.

[44] Samarasinghe, R., 2012. A Green Segmentation: Identifying the Green Consumer Demographic Profiles in Sri Lanka. International Journal of Marketing and Technology, 2(4), pp. 318-331.

[45] Sharpley, R., 2006. Ecotourism: A Consumption Perspective. Journal of Ecotourism, 5(1-2), pp. 7-22.

[46] Shiffman, L. G., Wisenblit, J. \& Kumar, S. R., 2015. Consumer Behavior. New Delhi: Dorling Kindersley (India) Pvt. Ltd.

[47] Stryker, S. \& Beurke, P. J., 2000. The Past, Present, and Future of an Identity Theory. Social Psychology Quarterly, Volume 63, pp. 284-297

[48] Tallontire, A., Rentsendorj, E. \& Blowfield, M., 2001. Policy Series 12, Ethical Consumers and Ethical Trade: A Review of Current Ltureitera, s.l.: Natural Resources Institute University of Greenwich. 
[49] The Institute of Grocery Distribution, n.d. http://www.igd.com/Research. [Online], Available at: http://www.igd.com/Research/Sustainability/Ethical-consumerism/

[50] Thefreedictionary.com, n.d. http://www.thefreedictionary.com/moral+obligation. [Online], Available at: http://www.thefreedictionary.com/moral+obligation

[51] TIES, 1990. https://www.ecotourism.org/book/ecotourism-definition. [Online], Available at: https://www.ecotourism.org/book/ecotourism-definition

[52] TIES, 2015. https://www.ecotourism.org/what-is-ecotourism. [Online], Available at: https://www.ecotourism.org/what-is-ecotourism

[53] Tsiotsou, R., 2006. The role of perceived product quality and overall satisfaction on purchase intentions. International Journal of Consumer Studies, p. 207-217.

[54] Weisstein, F. L., Asgari, M. \& Siew, S., 2014. Price presentation effects on green purchase intentions. Journal of Product \& Brand Management, 23(3), pp. 230 - 239.

[55] Whitmarsh, L. \& O'Neill, S., 2010. Green identity, green living? The role of proenvironmental self-identity in determining consistency across diverse pro-environmental behaviours. Journal of Environmental Psychology, Volume 30, p. 305-314.

[56] William,.S.,http://ecowanderlust.com/ecotourism-2/growth-global-ecotourism-industry/1487. [Online], Available at: http://ecowanderlust.com/ecotourism-2/growth-global-ecotourismindustry/1487

[57] Witkowski, T. H., \& Reddy, S. (2010). Antecedents of ethical consumption activities in Germany and the United States. Australasian Marketing Journal, 18, 8-14.

[58] Wood, L., 2000. Brands and brand equity: definition and management. Management Decision, 38(9), pp. 662-669.

[59] World Travel and Tourism Council, 2015. Travel and Tourism: Economic Impact 2015 Sri Lanka, London: World Travel and Tourism Council.

[60] World Travel and Tourism Council, 2016. Travel and Tourism: Economics Impact 2016 Sri Lanka, London: World Travel and Tourism Council.

[61] Yoo, J. \& Park, M., 2016. The effects of e-mass customization on consumer perceived value, satisfaction, and loyalty toward luxury brands. Journal of Business Research.

[62] Yang, Y., Solgaard, H. S., \& Haider, W. (2015). Value seeking, price sensitive, or green? Analyzing preference heterogeneity among residential energy consumers in Denmark. Energy Research \& Social Science, 6, 15-18.

[63] Yuksel, U., 2013. Non-participation in Anti-consumption: Consumer Reluctance to Boycott. Journal of Macromarketing, 33(3), pp. 204-216. 
